\title{
Western European Political Science: An Acquisition Study
}

\author{
Barbara Walden, Charles Fineman, \\ William S. Monroe, and Mary Jane Parrine
}

\begin{abstract}
National bibliographies from 1990 for France, Italy, Sweden, Belgium, Iceland, and Catalonia (Spain) formed the basis for a study of U.S and Canadian acquisitions in the field of Western European political science materials. Of the materials deemed important to be available in at least one research library in the United States or Canada, 15 percent of French, 30 percent of Italian, 55 percent of Swedish, 19 percent of Catalan, 75 percent of Icelandic, and 57 percent of Belgian materials were not found in a search of RLIN and OCLC. The citations were further examined for patterns of ownership, and it was found that in some cases traditional collecting patterns and agreements still seemed to be functioning to bring some materials into libraries, but in other cases a lack or decline of traditional commitments meant that these countries were particularly underrepresented in research library collections. Factors in addition to acquisition funding were identified as important in providing for adequate collecting levels. These include adequate staff in collection development and acquisitions, as well as attention to cataloging these materials and making information about their availability accessible.
\end{abstract}

n 1992 the Western European Specialists Section (WESS) of the Association of College and Research Libraries was approached by the Association of Research Libraries (ARL) with a request for assistance in a major grant-funded project to study the acquisition and availability of foreign materials in American research libraries. The ARL hoped to work with both library and scholarly area-study and other groups with a stake in the availability of foreign materials from around the world in American and Canadian libraries. Asubcommittee of the Research and Planning Committee of the Western European Specialists Section was appointed to work with the ARL on this project. The preliminary report of this subcommittee (March 26, 1992) noted the linguistic and geographic diversity of Western Europe and its diverse book trade. It noted that Western European acquisitions tend to

Barbara Walden is History Bibliographer at the University of Minnesota, Minneapolis, Minnesota; Charles Fineman is West European Bibliographer at Harvard University, Cambridge, Massachusetts; William S. Monree is Head, Collection Development at Brown University, Providence, Rhode Island; and Mary Jane Parrine is Curator of Romance Languages at Stanford University, Palo Alto, California. The authors wish to express their thanks to the following individuals: Anthony Angiletta, Director of Collections, Stanford University; Andrea Johannsdóttir and her colleagues of the library at Háskoli Íslands; Agnes Peterson, Curator, Western European Collections, Hoover Institution; Jutta Reed-Scott, Senior Program Officer, Association of Research Libraries; David Rozkuszkn, Foreign Documents Librarian, Stanford University; Mariann Tiblin, Scandinavian Bibliographer, University of Minnesota. 
be taken for granted in many large libraries and thus have possibly not received the study and attention given to other areas where acquisition is perceived to be more difficult. The tendency of libraries to fold Western European acquisitions into general acquisitions also makes it difficult to study and quantify trends in this area. The authors of the report also noted an increasing demand among scholars for nonbook materials as well as for current materials, including so-called gray literature in the social sciences. One recommendation of this report was the suggestion that an attempt be made to look at library acquisitions in an area of the social sciences where current information is essential and where there has been increasing interest by scholars in the United States and Canada. Political science was suggested as a potential topic for further study. This suggestion was accepted, and the subcommittee was asked to design and execute a study of recent acquisitions in political science, with the cooperation and assistance of the ARL.

\section{METHODOLOGY}

Citations were collected from the political science sections of the 1990 national bibliographies of Belgium, France, Italy, Sweden, Iceland, and Catalonia (Spain). In each case the items selected were only those which subcommittee members, as knowledgeable bibliographers, considered to be suitable for the collections of a large research library in the United States or Canada. Because of the differences in the individual national bibliographies, other considerations, noted below, also were taken into account. In all, there were 704 selected items: 319 French, 144 Italian, 133 Belgian, 68 Swedish, 32 Catalan, and 8 Icelandic. Mary Jane Parrine was responsible for the French and Italian selections, Charles Fineman created the set of Icelandic and Catalan items, William Monroe made the first pass through and final analysis of results from the Belgian national bibliography, and Barbara Walden did the Swedish national bibliography and the second pass through the Belgian national bibli- ography, and served as editor and gatekeeper for the others.

This set of citations was then searched in both OCLC and RLIN. This searching was carried out by Anastasia Leshinsky of Harvard University. Items discovered to be held in no locations were noted especially, as were those in only one location, in order to see if items little-held were clustered in any particular institutions. Ms. Leshinsky also printed out the complete lists of locations for items found so it was possible to check further for clustering of lesser-held materials in individual institutions and to note which, if any, items were widely held.

\section{RESULTS}

To summarize the results briefly, of the items listed in the French national bibliography, 15 percent were not held in the United States or Canada (i.e., not found in OCLC/RLIN). In actual numbers 49 out of a total of 318 French items were not held anywhere. In the Italian national bibliography, 30 percent of the items selected were not held anywhere (44 of 144); in the Swedish national bibliography, 55 percent of the items were not held anywhere (37 of 68); 19 percent of Catalan items were not found anywhere (6 of 32); of the Icelandic items, 75 percent were not held anywhere (6 of 8); and 57 percent of Belgian items were not found anywhere (74 of 133). Items found in only one location did not always cluster at such expected institutions as the Library of Congress, although this tended to vary among the countries examined. A more detailed discussion of the methods and results follows.

\section{FRENCH AND ITALIAN POLITICAL SCIENCE}

\section{Summary of results}

The study has contributed useful information, even with a few qualifications that should be mentioned. Limitations include the relatively narrow range of titles that could be checked, the difficult bibliographic access of some works listed, idiosyncracies of the national bibliographies, and the fact that the national 
databases, notably RLIN, are significantly behind in the entry of new acquisitions. The observations noted below represent a subjective overview of findings, reflecting personal views and consultation among colleagues in European studies at Stanford.

\section{Because the Italian national bibliography is more selective and its titles more representative of larger categories, the percentage of titles not held is more worrisome.}

In French studies, the statistics indicate that of a rather large sampling (318 titles of a total of 481 in the "politique" section of the Bibliographie Nationale Française), 15 percent are neither in OCLC nor RLIN. An additional 6 percent are held at only one location; though almost half of these are at the Library of Congress, the others are each at different institutions. Lacunae are in many cases significant, as are indications that certain types of material are poorly distributed among United States libraries. In Italian studies, the findings are more striking: of a smaller sample (144 titles from 10 issues of the Bibliografia Nazionale Italiana), close to 30 percent were held in neither database. Only 3 percent are held at one location, and of these only one is at the Library of Congress. Because the Italian national bibliography is more selective and its titles more representative of larger categories, the percentage of titles not held is more worrisome.

The range of materials in the bibliographies is far from a complete listing of all French or Italian publishing on political science. It is a limited cross section of publishing that does not include allied fields that can be seen in general publishing records (e.g., the "Résultats par catégories de livres"' in the yearly Édition de Livres en France). Even within the national bibliographies, the sample is artificially low, since the sections "politique" (section 32 in the BNF) or "lo stato" (320 in the BNI) leave out other categories such as economics and law that would need to be included in a full analysis of the field. Thus to estimate a core of titles needed, it would be necessary to assume an increase of perhaps 20 percent beyond the numbers found in these official listings.

The cost of a research-level collection in French and Italian political science may be roughly estimated from the lists checked, even with their limited scope. If we use just the titles identified in the two sections of the 1990 French and Italian national bibliographies and extrapolate total figures based on items that would be selected in three sample months, the totals would be approximately 348 French titles per year (about $\$ 12,188$ ) and approximately 204 Italian titles per year (about $\$ 7,140$ ). Both of these figures would need to be adjusted upward by about 20 percent to take other relevant publications into account.

\section{Characteristics of Titles Not Held}

For both French and Italian studies there is poor coverage of the following areas: local administration, elections, unions, nonmainstream political parties, and memoirs of individual politicians. In both areas, dates of publications indicate that many items would be out of print or very difficult to obtain by the time they appear in the national bibliographies. The overall characteristics are somewhat provisional, since they cover only a segment of publishing in political science and since their selection and ranking depend for this report on the judgment of one bibliographer for each geographic section.

\section{French}

Of the titles not found, about twothirds are mainstream, useful works. A smaller group is of particular importance, and an even smaller group is of marginal value, or of value to only the most specialized collections. An abbreviated list of items not found shows several global studies, i.e., comparative or general studies of politics that may fall between selectors' areas, and several studies on non-European areas, mainly Northern and Sub-Saharan Africa, as 
well as studies of Eastern European politics. This indicates that we are doing reasonably well with area-specific selections in French studies, but not as well with French publications on other parts of the world.

In many cases, the missing items may be termed gray literature, or alternative publishing that must be acquired through correspondence or direct contact with authors or publishers rather than through approval plans or routine acquisition methods.

Government publications total about a fourth of the forty-four titles not found, and pose a problem for both acquisitions and collection evaluations. Since institutional citations are difficult to check in a quick project, many of those apparently missing titles may be found through more painstaking investigation of corporate entries, subseries' titles, and backlog records that often are listed by only the most general access points. In many cases, the library records simply do not match those of the national bibliography. This is true especially for the frequent gaps in holding on the "cabinets ministeriels" and the various editions of Michel Rocard's papers published by Tris$\tan$ Mage. And for a thorough study of United States holdings on French politics, it would be necessary to use other sources than the BNF. One of the most crucial would be lists from the Documentation Française, which selects and organizes official publications. More focused catalogues would also be preferable to the capacious coverage of the BNF, notably those of the Centre National de la Recherche Scientifique (CNRS), the Institut National de la Statistique et des Études Économiques (INSEE), the Office de la Recherche Scientifique et Technique Outre Mer (ORSTOM), or the Imprimerie $\mathrm{Na}$ tionale. The problem with using the BNF alone for government documents is that it includes too much marginal government material that is not as essential to United States libraries as titles filtered through main official publishing agencies. Thus for this important segment of publishing on politics, our study is of less value.

\section{Italian}

About 80 percent of the titles not found are solid, mainstream materials. Within those, a smaller group includes works of particular importance. Those titles not held tend to be of more potential scholarly use than the comparable group of French titles. While the BNI is virtually useless now as a selection source for current publications, it is useful in evaluations, since its coverage is less expansive than the BNF. Of the titles not found, most are on Italian politics, rather than on general political themes. They include memoirs of deputies and other government officials, local history, and statements of political parties. Among the titles of particular interest are a study on women in parliament, a history of the Partito Liberale, a guide to university departments of political science, a German/Italian study on the European space program, and a speech by Norberto Bobbio on the bicentennial of the French Revolution.

\section{Costs and the Margin of Distinction}

Though it is impossible to assign exact costs to lists of titles not found, some general observations can be made. Using 1990 prices and the exchange rate of February 12, 1993 (1,542 lire/dollar; 5.61 francs/dollar), the prices of these materials would not be substantial. They would of course be higher now due to inflation, possibly up 10 to 15 percent. At 1990 prices, the highest priority group ( 8 items selected) of French titles would require about $662 \mathrm{~F}$, or $\$ 118$ to acquire. The whole list of items not found would cost around $\$ 1,800$. For Italy, the comparable prices would be about 103,000 lire or $\$ 67$ for highest priority material, and perhaps $\$ 1,500$ for the whole set of titles not found.

The total price of these books, however, is not the key factor in determining cost. This would be true even if we were to add today's inflationary increase. In many cases, the missing items may be 
termed gray literature, or alternative publishing that must be acquired through correspondence or direct contact with authors or publishers rather than through approval plans or routine acquisition methods. In all cases they are obtained through the careful attention of selectors who must spend a growing proportion of their time scanning larger ranges of selection sources, and through specialized technical processing that assures timely acquisition and access. Thus the total cost must be seen in the context of staff effort and commitment, a consideration underscored as a conclusion of this study.

\section{BELGIAN POLITICAL SCIENCE}

The Belgian national bibliography (Belgische Bibliografie/Bibliographie de Belgique) is all-encompassing. It includes many small internal publications and much gray literature-publications of societies and institutes not part of the book trade-as well as government materials and major trade publications. The political science section is defined as "political economy" and includes information on banking, sociology, finance, and economics as well as politics and political affairs. For purposes of the study, items on internal banking and finance, public administration, economics, and some of the sociology materials were eliminated. Publications on international business were included. Also eliminated were theses, publications of fewer than fifty pages published as part of a series, offprints, sections, chapters (i.e., less than whole works), non-Belgian imprints, translations from other languages into Flemish (for materials published in both French and Flemish, French was chosen), government publications not likely to be cataloged by owning libraries, and publications not suited to academic or research libraries. (See table 1.)

Of 133 items selected, 74 (57 percent) were not in OCLC/RLIN. An additional . 13 items ( 10 percent) were only found in one location. A significant proportion of the items not found appeared to be fairly substantial monographs published by political institutes and organizations
TABLE 1 MAJOR CONCENTRATIONS
OF BELGIAN HOLDINGS

\begin{tabular}{ll}
\hline Library of Congress (DLC) & 47 (15 unique) \\
Harvard (MH) & 24 \\
University of Indiana (InU) & 12 (4 unique) \\
University of California (CU) & 11 \\
University of Virginia (ViU) & 11 \\
UCLA (CLU) & 10 \\
Princeton (NjP) & 10 \\
University of Wisconsin (WU) & 9 \\
\hline
\end{tabular}

(i.e., "gray" literature.), as well as trade publications. Of the items found in only one location, the Library of Congress was the owning institution in most cases and also was the most frequently reported owning institution in cases where fewer than five owning institutions were reported. Flemish-language materials were a large proportion of the items not found, a point perhaps worthy of additional attention in view of the political volatility of the linguistic question in Belgium. (See table 2.)

Further, the tradition of coverage of Belgium by linguistic specialists concentrating either on Romance or Germanic-language materials may not be the best arrangement for a country where the linguistic boundaries result in little cooperation among its people.

No other library held more than five titles. University of Illinois (IU) and University of Michigan (MiU) each held five. Only two other libraries held unique titles, with one each. Overall, the holdings were shared by at least 89 libraries, with 36 holding more than one of the titles. Many of these titles could also be considered twentieth-century history. If these results are compared with the RLG Conspectus for history, two libraries indicating collecting levels of 4 / 4 for twentieth-century Belgian his- 
TABLE 2

EXAMPLES OF BELGIAN TITLES NOT FOUND

Les actions positives en faveur des femmes en Europe occidentale. Bruxelles: Institut syndical européen, 1989. 109 p., diagr., tab. (Rapports/Institut syndical européen, 35).

Cobbaut, Willy. Het fatale dwangdenken. Baardegem bij Aalst: Boekenactie Alternatief, 1988. 367p.

Contactgroepen humane en politieke wetenschappen. Brussel: Nationaal Fonds voor Wetenschappelijk Onderzoek, 1986.

Coppe, Michel. Les travailleurs aussi fabriquent l'histoire de la FN. Liège: Fondation André Renard, 1989. 111p.

Deboeure, Sylvia. Socialistische vrouwen uit het Antwerpse/research en teksten. Berchem: FRESIA, 1986.

De Landtsheer, Christ'1. De politieke taal in de Vlaamse media. Deurne: Kluwer, 1987. xvii, 121p. (Kluwer politieke bibliothek)

Delestienne, Paul Questions approfondies relatives à la déclaration à l'impôt des sociétés et la déclaration a l'impôt des non-résidents sociétés. Bruxelles: Presses Universitaires de Bruxelles, 19881989. 220p. (no edition found).

De Schuyter, Inge. Geschiedenis van het Belgisch liberalisme, 1830-1987: een selectieve bibliografie. Gent: Liberaal Archief, 1989. 76p. (Reeks Bibliographieën, 2)

Diagnostics: enjeux sociaux et politiques en Belgique. Bruxelles: CIACO, 1989. 296p.

Fonteyn, Guido. De nieuwe Walen: met een inleiding over het Belgisch model. Tielt: Lannoo, 1988. $143 p$.

Frauenfördermassnahmen in Westeuropa. Brüssel: Europäisches Gewerkschaftsinstitut, 1989. 116p.

tory, Yale and Stanford, held only one each of the titles. The New York Public Library held only three of the titles.

While not definitive, these results do seem to indicate that materials from Belgium are in need of systematic attention within the community of large research libraries, perhaps with one institution taking the lead in collecting these materials and assigning staff and funding for coverage. Unlike Swedish and Catalan, Belgian materials are not the object of special interest in one or several libraries, and so are relatively poorly covered. Further, the tradition of coverage of Belgium by linguistic specialists concentrating either on Romance or Germanic-language materials may not be the best arrangement for a country where the linguistic boundaries result in little cooperation among its people. When these linguistic groups are themselves at odds within the country, it seems more advisable for coverage within the library not to be split.

To purchase all of the materials which were not found in OCLC/RLIN would cost, at the exchange rate of February 16, $1993,29,163$ Belgian francs or $\$ 869$ (BEF $=\$ .03002$ ). Inflation would probably bring the actual cost to around $\$ 1,000$. Since the actual cost of purchasing the materials not found was not high, these data would seem to suggest that other factors also play a role in nonacquisition of Belgian materials.

\section{SWEDISH POLITICAL SCIENCE}

The Swedish national bibliography (Svensk Bokförteckning) divides political science into components including international relations, internal politics, public administration, general political science and politics, and political party publications. Entries follow AACR-2 conventions and are accurate and thorough. Publications of fewer than fourteen pages are excluded, as are offprints and sections of larger publications, and purely internal materials. Gray literature such as publications of scholarly institutions is included. For purposes of this study, entries were selected from the sections on international relations, 
TABLE 3

\section{EXAMPLES OF SWEDISH TITLES NOT FOUND}

60 år för freden: Svenska FN-förbundet och dess föregaingare 1929-1989/redaktör Lars Eriksson. Stockholm: Svenska FN-förb., 1990. 136p.

Axelsson, Elsie, Tumma inte pd demokratin! om seniors rätt att delta i politisk beslut: redovisning av en undersökning $i 74$ kommuner. Järfälla; REKO, 1990. 107p. tab.

Bohlin, Alf. Offentlighetsprincipen. Stockholm; Juristförl., 1990. 166p.

Dahlén, Marianne. Europeisk union: framväxten av ett enat Europa. Uppsala: Iustus, 1990. 72p.

The Great peace journey/le grand voyage de paix/den stora fredsresan ... Stockholm; Great Peace Journey, 1989. 112p.

Holstad, Sigvard. Sekretess i allmän verksamhet: en vägledning till de grundläggande reglerna $i$ tryckfrihetsförordningen och sekretesslagen. Stockholm: Allmanna forl. 1990. 236p.

Martinez Wilson, Fernando. Den antarktiska problematiken. Stockholm: Editorial Latinoamericana, 1989. 66p.

Nordic development studies: handbook 1990. Compiled and edited by Jöran Carlsson. Göteborg: Nordic Working Group for Development Studies (NORDDEV), 1990. 154p.

Palme, Susanne. Hemliga krigare: om USA's militärstrategi i tredje världen. Stockholm: Brevskolan, cop. 1989. 108p.

Petersson, Olof. Makten över tanken: en bok om det svenska massmediesamhället. Stockholm: Carlsson, 1990. 247p.

En värld utan vapen: nedrustningspolitken i brytningsskede; en historisk dokumentation. Stockholm: Arbetsgruppen för Svensk folkriksdag för nedrustning, 1990. 468p.

internal politics, and general political science and politics. Excluded were theses, small items in a larger series which did not appear likely to be separately cataloged by American libraries, items designated by the national bibliography as "non-Swedish imprints," and items judged not to be of interest to academic or research libraries.

Sixty-eight items were selected. Of these thirty-seven ( 55 percent) were not found in RLIN or OCLC. An additional six ( 8 percent) were found in only one location. Items with more than five owning institutions were almost exclusively English-language materials. Items not found included journalistic accounts, trade publications, and gray literature. (See table 3.) Of items with only one location, no one institution emerged where materials clustered. For items with few locations or only one location, a group of institutions emerged as owners (in descending order): University of Washington, Harvard University, University of Wisconsin, University of Minnesota, University of Indiana, the Library of Congress. These are, for the most part, institutions with Scandinavian area specialists and established programs of Scandinavian acquisitions. These findings seem to suggest that additional attention to Scandinavian materials in institutions where they are already systematically collected might be a successful strategy for improving coverage of these materials. Informal cooperative collection development arrangements have been begun among Scandinavianist librarians, but these librarians have also observed that many of the difficulties in this area arise not solely from lack of funding for acquisitions but also from declining availability of support staff and increasing pressure for the time of area studies librarians to be spent outside of selection and collection development. Cataloging and making these foreign-language materials accessible is also of concern.

Prices were not available for some of the items not found; however, most did have price information. The total price for all items not found in OCLC/RLIN was Kr.3,890.00, or U.S. $\$ 535.00$ at the exchange rates of February 16, 1992 
$(\mathrm{Kr} .=\$ .1372)$. Inflation would probably make today's prices closer to $\$ 800$.

\section{CATALAN POLITICAL SCIENCE}

The data from the Catalan-language sample are most encouraging, even unexpectedly brilliant. The Catalan language is still not widely taught at U.S. universities. Nevertheless, the finding that a very high percentage of titles in the national bibliography sample are held somewhere in the United States does suggest that knowledgeable selectors located at institutions which give them adequate financial leeway to make decisions can work together with faculty, keep up on current developments in research and publishing, and acquire foreign language research materials in quantities adequate to support present and future needs.

The cost of covering this subject area for this language for the year under review even more exhaustively would have been a modest U.S. $\$ 85$ (estimated); most of the six titles not held anywhere in the U.S. appear to be of the highest priority. With regard to the emerging national map of foreign-language resources, the biggest Catalan-language collections, not surprisingly, appear to be those at (in descending order of importance): the Library of Congress, the University of California-San Diego, the New York Public Library, Harvard, and the University of California-Berkeley. With regard to institutions holding significant numbers of Catalan-language materials in this area, the pattern with regard to issues such as geographic spread, mix between public and private, etc., would appear to be healthy. Twenty-two other institutions shared some of the other titles. In this area, at least, existing arrangements and understandings, coupled (especially in the case of the University of California-San Diego) with historic collecting strengths, appear to be working to the benefit of the research community.

Publishing in the Catalan language in this area will continue to be brisk. The specific areas covered will, of course, concentrate on Catalonian and Spanish is- sues, but there is also a very clear emerging Euro-focus to some of the titles which, one suspects, will only grow with time and further European integration.

\section{ICELANDIC POLITICAL SCIENCE}

This was the smallest sample taken for this segment of the study, yet it adequately reflects the publishing patterns in this very small publishing universe. The results, insofar as it is prudent to extrapolate from them, are not reassuring in terms of national-level cooperation and planning in the area of collections on less-studied areas. The Library of Congress was the only institution reporting any holdings of any of the titles in this sample. A subsequent inquiry at the Fiske Collection at Cornell which traditionally has been a mainstay of Icelandic collecting uncovered one title in its uncataloged backlog.

\section{What has now come to be labeled the North Atlantic area of Western Europe (i.e., Faeroes, Iceland, Greenland) is poorly represented in U.S. collections today.}

Cost of materials is clearly not the issue with Iceland, even if locally the rate of inflation in the cost of books is quite wild and unpredictable. It would have cost only U.S. $\$ 110$ to acquire the six titles in the sample not held anywhere in the United States, and at least two of these six were, roughly speaking, government publications which would have been available free upon request to the appropriate office of Parliament. What has now come to be labeled the North Atlantic area of Western Europe (i.e., Faeroes, Iceland, Greenland) is poorly represented in U.S. collections today. The three indigenous languages are small and (generally speaking) little studied except by specialists, yet despite poor current economic conditions, publishing there is fairly active. Whether in the post-cold war environment this area can again be seen as having strategic importance for the United States is still 
a debatable point; where research libraries are concerned, the most modest of efforts would certainly be repaid.

\section{CONCLUSIONS AND RECOMMENDATIONS}

There is cause for concern about materials from larger areas such as France and Italy, and smaller areas such as Iceland, as well as some pleasant surprises as in the case of Catalan. In the case of both Catalan and Swedish, there is some indication that the work of a few institutions is providing some national support for collections. In the case of Belgium and Iceland, the Library of Congress seems currently to be the major national support for in-depth collecting. It is striking that the dollar amount needed for acquisition of additional materials in political science is relatively small. However, it does seem unwise to infer from this that little additional acquisitions funding is needed to bring library collections up to desirable levels; it should be remembered that this study involved a deliberately small sampling of one subject for one year. Nevertheless, this brief study would seem to indicate that other factors are also important. These too involve funding and a choice of priorities.

Rather than consider price alone, the crucial factor is the whole range of costs involved in acquiring material. Here, the importance of committed staff is essential. This means both quantity and quality of selectors and their support staff, as well as institutional commitment to insure full use of staff to obtain material that goes beyond a minimal or basic level of collecting. Without that commitment, it will not be possible to reach the margin of distinction exemplified by the group of titles that are not held in either of the national databases.

As the subcommittee described its work at meetings of the Western European Specialists Section, two additional areas of concern surfaced. These were cataloging backlogs and the national utilities. Questions of the availability of uncataloged materials were not addressed by this study, yet several WESS members voiced concerns that some of the unlocated or underreported items might actually be owned but not yet cataloged by owning libraries, or not yet reported to national utilities. Further inquiries at libraries expected to own some of these materials did in fact turn up a few additional holdings in cataloging backlogs, but for each country the numbers were not large enough to change the original results substantially; generally between one and three additional items were discovered.

Some collection development librarians also reported "selection backlogs" as the press of other duties brought selection and acquisition of current materials ever more into arrears. These cataloging and selection backlogs involve the major countries and languages of Western Europe, not just smaller ones or those perceived as marginal.

\section{As recent events in Europe suggest, no force on that continent is at present more potent or has a greater destabilizing potential than nationalism.}

The function of the bibliographic utilities as bearers of information for the scholarly community in the age of the Internet also impinges on these questions of availability and access. Perhaps it is time to take a closer look at the national databases: how can they be improved to indicate a fuller range of what is in United States libraries? There appears to be a need for better access in both national and local consortia. It seems unwise to put too much weight on the move toward Internet access to individual OPACs without also improving the larger networks. Authority control is an important part of this, especially as libraries increasingly treat foreign language material with minimal or intermediate level cataloging.

The Internet does offer some new possibilities for access to European databases. For France, for example, can we use Questel for online connections to the Bulletin Signalétique or use the French 
version, FRANCIS (now on CD-ROM) to gain access to publications so that we do not have to purchase them? This would depend on extended international agreements for interlibrary loan, expanded photocopying services, and greater online access to full-text documents. We may be able to use even MINITEL, the French electronic system that includes the general booktrade, for quicker access to new publications and assistance with an extended form of interlibrary loan.

There are also some encouraging signs that informal or traditional arrangements, as in Swedish and Catalan, still seem to be acting to make these materials available, although not at levels sufficient to encourage complacency. It would be well to build on and nurture such existing arrangements for smaller areas, and perhaps to create some new ones for areas not yet covered and to revive old ones that have fallen away. As recent events in Europe suggest, no force on that continent is at present more potent or has a greater destabilizing potential than nationalism. Here is a lesson for librarians concerned about our country's ability to document all facets of Western Europe, and an indicator of the need to be concerned with publishing in the so-called smaller or minority languages of Western Europe. The example of Catalan is, in this respect, almost atypical-publishing in the Catalan language flourishes because cultural, political, and economic arrangements have been made peacefully within the Spanish state to accommodate a language with a large speaker base and permit its manifestations, publishing among them, to flourish. While the case of Basque is less spectacular, progress has been made, though in the United States only one institution is on record with a commitment to collecting materials in Basque and making them available to researchers. Comparatively little attention has been paid to materials appearing in languages such as Irish and Scots Gaelic, Raeto-Romance, Gallegan, Sami, Frisian, Low German, or Occitan. The relative nonavailability of Flemish political science materials was noted in the Belgian study. Some of this material is elusive and would require special labor before libraries could identify and acquire it. Thus we may also need to revive the issue of primary collecting responsibilities. A better version of the RLG program and the Farmington plan needs to be formulated, one that incorporates both funding and staffing commitments.

It is clear that attention must be paid both to the large Western European publishing areas, such as French-language materials, and to languages and book trades that are less well known. Strategies for these areas may vary, but both involve commitments and priorities in addition to acquisitions funding alone. This political science study, while limited in nature, has served to raise a number of issues for acquisition and collection development. It is to be hoped that the information gathered through this and other ARL studies of foreign acquisitions may result in discussion, planning, and action for foreign materials in U.S. and Canadian libraries. 


\section{APPENDIX A}

WESTERN EUROPEAN POLITICAL SCIENCE

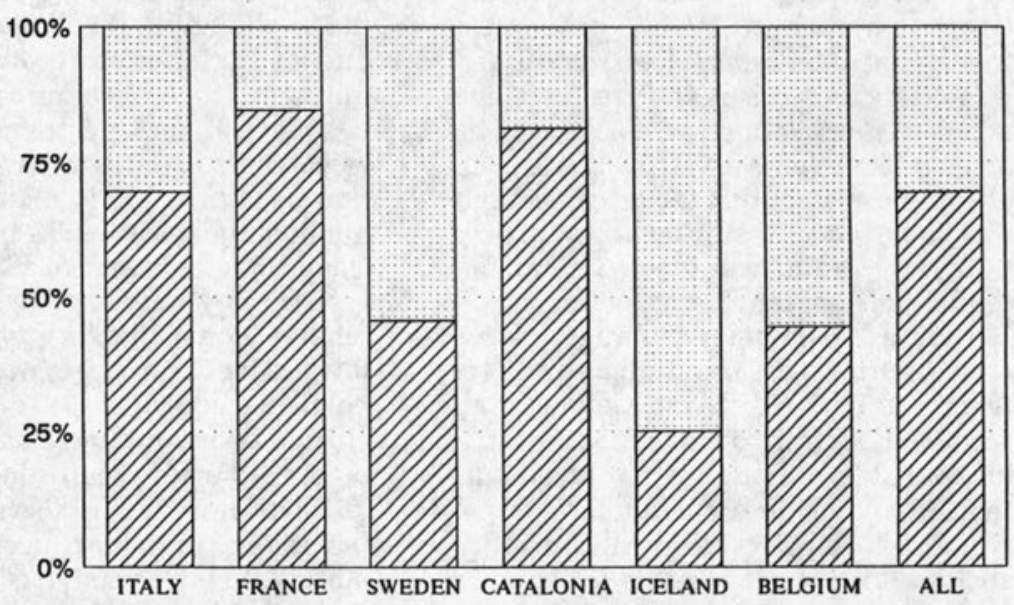

\begin{tabular}{|l|c|c|c|c|c|c|c|}
\hline NOT HELD $\square$ & 44 & 49 & 37 & 6 & 6 & 74 & 216 \\
\hline HELD $\square$ & 100 & 269 & 31 & 26 & 2 & 59 & 487 \\
\hline TOTAL & 144 & 318 & 68 & 32 & 8 & 133 & 703 \\
\hline
\end{tabular}

